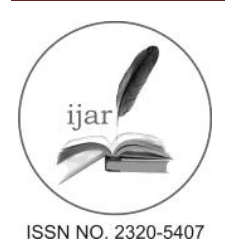

\section{Journal homepage:http://www.journalijar.com Journal DOI:10.21474/IJAR01}

\section{RESEARCH ARTICLE}

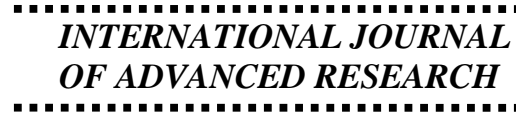

(1)

\title{
Leptin receptor LYS109ARG, GLN223ARG, SER343SER polymorphisms and obesity: Linkage disequilibrium and haplotype block analysis in Jeddah city.
}

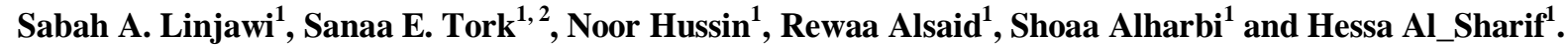

1. Biological department, Faculty of Science, King Abdulaziz University, Jeddah, Saudi Arabia.

2. Microbial Genetics Department, National Research Center, Dokki, Egypt.

\section{Manuscript Info}

Manuscript History:

Received: 12 May 2016

Final Accepted: 13 June 2016

Published Online: July 2016

Key words:

LEP, LEPR, obesity, SNP, PCR-

RFLP, haplotype.

*Corresponding Author

Sabah A. Linjawi.

\section{Abstract}

Single nucleotide polymorphisms in leptin receptor gene, which interacts with leptin hormone (LEP)may play an important role in the pathophysiology of human obesity. The current study aimed to investigate whether LEPR polymorphismswere associated with incidence of obesity or no in Saudi study group. A case - control study was conducted with 109 subjects from Jeddah, Saudi Arabia. Genomic DNAs were used as templates in polymerase chain reaction (PCR) with pairs of primers designed to amplify exons 4, 6 and 9 of the human leptin receptor gene. Genotype and allele frequencies were determined by PCR reaction followed by restriction fragment length polymorphism techniques.A highly significant association between Lys109Arg, and Ser343Ser polymorphisms and incidence of obesity was observed $(\mathrm{P}=0.017)$. Whereas no significant association between (Lys109Arg, Gln223Arg) and (Gln223Arg, Ser343Ser) combinations and incidence of obesitywas detected $(\mathrm{P}=0.38,0.195$ respectively). There was a preference for genotypes TT/TC and allele T of Ser343Ser SNP in obese subjects. It seems that the effect of polymeric sites Lys109Arg, Gln223Arg on incidence of obesity was abolished when the three SNPs was combined. The only key player on incidence of obesity was Ser343Ser polymorphism. In conclusion, the data achieved pointed to the genetic predisposition of LEPR variants in Saudi population. The impact of Ser343Ser polymorphism on incidence of obesity may varies among populations as a result of distinct differences in their allele distributions.

Copy Right, IJAR, 2016, All rights reserved.

\section{Introduction:-}

Obesity is an unhealthy excessive deposition of fat in the body caused by an imbalance between the energy that is ingested (Energy In) and the energy that is expended (Energy Out). Prevalence of obesity is growing strongly at an alarming rate all over the world to the extent that it is now considered a pandemic instead of the epidemic. This prevalence is rising without ceasing in Saudi population over the last thirty years; it's considered a major health problem where the total obesity reached in national studies on Saudis adults to 35.5\% (Al-Sultan and Al-Elq 2006; Marti et al. 2009; Al-Nozha et al. 2005)(Bahathiq, 2010). Moreover, the statistics of the World Health Organization (WHO) in 2008 estimated that the overall prevalence of obesity in Saudi Arabia arrived to 39.1\% in females and $28.6 \%$ in males.

Many genetic, metabolic, behavioral and environmental factors in addition to the sophisticated interaction among them affect significantly on the incidence of obesity (Malnick and Knobler 2006; Arslan, Erdur, and Aydin 2010)(Turconi and Cena, 2007). Above all, researchers believe that genetic factors along with the environment have a critical role in the etiology of obesity.Previous studies demonstrated that leptin and leptin receptorpolymorphisms have major influence on the development of obesity, depending on its fundamentalrole in the regulation of energy homeostasis and fat storage(Fan and Say 2014). 
Leptin is a hormone formed by adipocytes.It has a vital role in the body-weight regulation by means of reducing intake of food and enhancing expenditure of energy. Its effect occurs via the leptin receptor which encoded by the LEPR gene located on the short arm of chromosome 1, at position 1p31. LEPR gene constitutes of 18 exons and 17 introns encoding a protein of 1,172 amino acids (816 amino acids found in the extracellular domain, 303 constitute the intracellular domain and 23 in the transmembrane domain). Its expression occurs mainly in the hypothalamus, and known as the OB-RL isoform (OB-large receptor). Other minor isoforms are recognized, the smallest one is known as OBRS (short OB-receptor), which is produced in diverse tissues as the choroid plexus, lungs and kidneys(Chung et al. 1996; Fruhbeck 2001; Margetic et al. 2002; Bjorbaek and Kahn 2004)(Bagchi and Preuss, 2007).

Various LEPR mutations have been identified in individuals with severe obesity. An intronic mutation IVS16 +1 G> A in LEPR gene was detected in patients with early-onset severe obesity and pituitary dysfunction (Clement et al. 1998). Other two mutations (Lys109Arg and Gln223Arg) were identified by(Rosmond et al. 2000). Two polymorphisms have an influence against higher blood pressure levels. Individualscomprising arginine alleles carried lower blood pressure levels; the difference was higher when subjects carried arginine in both codons. In the same group, hypertensive subjects had higher BMI, leptin levels, and frequency of Lys109 allele. Five common polymorphisms (Lys109Arg, Gln223Arg, Ser343Ser, Lys656Asn, and Pro1019Pro)were identified, four of them found in the extracellular domain in the intracellular portion of the human Ob-R(Gotoda et al. 1997; Al-Sultan and Al-Elq 2006).

The current study aimed to investigate the association between Lys109Arg (rs1137100), Gln223Arg(rs1137101), Ser343Ser (rs1805134) of LEPR gene polymorphisms and the incidence of obesity in Jeddah population. The genomic DNA extraction from the collected samples,genotypes determination for all subjects by PCR amplification using specific primers followed by RFLP analysis, statistical analysis and interpretation of data were performed in obese and non-obese groups.

\section{Material and method: - Study of the population: -}

This study was approved by the ethical Committee (unit of biomedical ethics) of King Abdulaziz University. A total of 180 subjects (94 males and 86 females)aged from 6 to 27 were recruited from King Abdulaziz University Hospital in Jeddah after providing written informed consent of their participation. All the participants underwent complete physical examination and were asked to answer a questionnaire about family history of obesity and genetic diseases. All subjects were classified into two groups according to BMI obese (BMI $\geq 25)$ and non-obese (BMI < 25).

\section{Genetic analysis:- Genotyping:-}

Genomic DNA was extracted from whole bloodstored in EDTA (anticoagulant ethylenediaminetetraacetic acid) coated tubes by using Qiagen- Qiaamp DNA Blood Mini Kit. PCR-RFLP was performed to determine theallele and genotype frequencies for the three common variants of Leptin receptor gene (Lys109Arg, Gln223Arg and Ser343Ser)in the obese and non-obesegroupsaccording to the conditions described at the previous studies(Gotoda et al. 1997) (Guerola, 2008, Linjawi and Hussain, 2012, Linjawi and Al-Sayed, 2013, Linjawi and Al-Harbi, 2014). Results were visualized on 3\% (w/v) agarose gel electrophoresis.

\section{Haplotype structure and statistical analysis:-}

The obtained data was analyzed using SPSS for Windows, version 16 (SPSS Inc.). Descriptive data are given as means $( \pm)$, standard deviation (Clement et al.). The associations between BMI and other parameters with genotypes were evaluated using the nonparametric Mann-Whitney test. A 2-by-3 chi-square test was used to analyze the association between genotypes and clinical groups; moreover, a 2-by-2 test was applied to test the associationbetween alleles in clinical groups. Statistical significancewas defined as $\mathrm{P}<0.05$. The Hardy-Weinberg equilibriumwas assessed by a goodness-of-fit $\chi 2$ test by comparing theobserved genotype frequencies with the expected genotypefrequencies among the obese and non-obesegroups, with the chi-square test featuring one degree of freedom. 


\section{Results:- \\ Allele and genotype Frequencies of LEPR Lys109Arg (rs1137100) and Gln223Arg (rs1137101) variants in 100 subjects:-}

To evaluate a possible additive effect of LEPR polymorphisms in Jeddah population, the combination of exon $4 \mathrm{~A} /$ $\mathrm{G}$ (rs1137100) and exon $6 \mathrm{~A} / \mathrm{G}$ (rs1137101) genotype alleles was analyzed in relation to groups (normal and obese). Nine genotype alleles were defined (AAAA, AAAG, AAGG, AGAA, AGAG, AGGG, GGAA, GGAG and GGGG). The frequency of the genotype combinations in 100 subjects was demonstrated (Table 1). When the two polymorphisms were combined together, six genotype alleles were recognized (AAAA, AGAA, AAAG, AGAG, AAGG, AGGG). The other possible genotypes (GGAA, GGAG and GGGG) were undetected.No association according to linkage disequilibrium (LD) between exon 4 A/ G (rs1137100) and exon 6 A/G (rs1137101) polymorphisms was observed $(\mathrm{P}=0.38)$. The frequencies of genotype in normal and obese group were demonstrated in Table 1. The obese cases had frequencies of $44.9 \%(n=22), 4.1 \%(n=2), 34.7 \%(n=17), 8.2 \%(n=4), 4.1 \%(n=$ $2)$ and $4.1 \%(\mathrm{n}=2)$ for the following haplotypes AAAA, AGAA, AAAG, AGAG, AAGG, AGGG respectively, whereas the non-obese cases were found to have $35.3 \%(n=18), 13.7 \%(n=7), 23.5 \%(n=12), 17.6 \%(n=9), 5.9 \%$ $(\mathrm{n}=3)$, and $3.9 \%(\mathrm{n}=2)$. The alleles frequencies in normal and obese cases were indicated in Table 1 , the frequencies of obese group were $68.37 \%(\mathrm{~N}=67), 23.47 \%(\mathrm{~N}=23), 2.04 \%(\mathrm{~N}=2)$ and $6.12 \%(\mathrm{~N}=6)$ for the corresponding alleles AA, AG, GA and GG respectively. Whereas, in case of normal subjects, there were $62.7 \%$ $(\mathrm{N}=64), 6.9 \%(\mathrm{~N}=7), 19.6 \%(\mathrm{~N}=20)$ and $10.9 \%(\mathrm{~N}=11)$.

The distributions of genotype were in Hardy-Weinberg equilibrium meaning that the balance between homozygotes and heterozygotes was as predicated by the Hardy-Weinberg equation (HWE) from these allele frequencies (Goodness of fit X2 $=11.67, \mathrm{df}=1, \mathrm{P}=0.0001)$ (Goodness of fit $\mathrm{X} 2=7.09, \mathrm{df}=1, \mathrm{P}=0.01$ ) in normal and obese subjects, respectively.

Haplotype analysis betweenexon 4 A/ G (rs1137100) and exon 6 A/G (rs1137101) was shown in Table 2. All the possible haplotypes (AA, AG, GA and GG) were detected with frequencies of $\mathrm{A}-\mathrm{A}=65.5 \%, \mathrm{AG}=21.5 \%, \mathrm{GA}=$ $4.5 \%$ and $\mathrm{GG}=8.5 \%$ (Table 2). Our obtained results indicated that the haplotype A-A exon 4, exon 6 was the most common $(65.5 \%)$ while the frequency of other haplotypes, A-G and G-G was $21.5 \%$ and $8.5 \%$, respectively. The frequency of the rare haplotype G-A was $4.5 \%$. Haplotype analysis produced a strong significant association with obesity $(\mathrm{P}=0.04)$ as shown in Table 2 .

\section{Allele and Genotype Frequencies LEPR Lys109Arg (rs1137100) and Ser343Ser (rs1805134) variants in 95 subjects:-}

Thecombinationbetween exon 4 A/ G (rs1137100) and exon 9 T/C (rs1805134) polymorphisms was analyzed in relation to BMI groups (normal and obese). Nineexpected genotype alleles weredetermined (AATT, AGTT, GGTT, AATC, AGTC, GGTC, AACC, AGCC and GGCC). Six observed genotype alleles were identified (AATT, AGTT, AATC, AGTC, AACC, AGCC). The other possible genotypes (GGTT, GGTC and GGCC) were unnoticed (Table 3). Genotype combinationfrequenciesfor 95 subjects wereshowed in Table 3. A highly significant association in terms of linkage disequilibrium (LD) between exon 4 A/ G (rs1137100) and exon 6 A/G (rs1137101) polymorphisms was observed $(\mathrm{P}=0.017)$. Genotype frequencies of normal and obese group were revealed in Table 3 . The obese cases had frequencies of 58\% ( $n=29), 10 \%(n=5), 26 \%(n=13)$ and $6 \%(n=3)$ for the following haplotypes AATT, AGTT, AATC, AGTC respectively. The other genotypes, AACC, AGCC were undetectable in obese group. Whereas the non-obese cases had $37.8 \%(n=17), 17.8 \%(n=8), 15.6 \%(n=7), 11.1 \%(n=5), 13.3 \%(n$ $=6)$, and $4.4 \%(\mathrm{n}=2)$. Moreover, the allele frequencies of obese group were found to be $79 \%(\mathrm{~N}=79), 13 \%(\mathrm{~N}=$ 13), $5 \%(\mathrm{~N}=5)$ and $3 \%(\mathrm{~N}=3)$ for the following alleles $\mathrm{AT}, \mathrm{AC}, \mathrm{GT}$ and $\mathrm{GC}$ respectively. Where, in case of normal subjects, there were $60 \%(\mathrm{~N}=54), 23.3 \%(\mathrm{~N}=21), 8.9 \%(\mathrm{~N}=8)$ and $7.8 \%(\mathrm{~N}=7)$.

The distributions of genotypemet the Hardy-Weinberg expectations in both groups (normal and obese cases) (Goodness of fit $\mathrm{X} 2=9.18, \mathrm{df}=1, \mathrm{P}=0.0005)$ (Goodness of fit $\mathrm{X} 2=3.53, \mathrm{df}=1, \mathrm{P}=0.05)$ respectively.

Haplotype analysis betweenexon 4 A/ G (rs1137100) and exon 6 A/G (rs1137101) was performed. All the possible haplotypes (AT, AC, GT and GC) were identified with frequencies of $\mathrm{A}-\mathrm{A}=70 \%, \mathrm{AG}=17.9 \%, \mathrm{GA}=6.8 \%$ and $\mathrm{GG}=0.5 \%$ (Table 4). The obtained results revealed that the haplotype A-T exon 4, exon 6 was the most common (70\%) whereas the frequency of other haplotypes, A-C and G-T was $17.9 \%$ and $6.8 \%$, respectively. The frequency of the rare haplotype G-C was $0.5 \%$. Haplotype analysis displayed a highly significant association with obesity $(\mathrm{P}=$ 0.028 ) as shown in Table 4. 


\section{Allele and Genotype Frequencies Gln223Arg (rs1137101) and SER343SER (rs1805134) variants in 109 subjects:-}

Table 5 summarized the frequencies of genotype and allele for the combination of Gln223Arg (rs1137101) and Ser343Ser (rs1805134) variants in 109 subjects. The predicated genotypes were found to be AATT, AGTT, GGTT, AATC, AGTC, GGTC, AACC, AGCC and GGCC. When we combined the two polymorphisms together in this study, all genotypes were recognized.There was no significant difference in genotype between groups (normal and obese) $(\mathrm{P}=0.196)$. Furthermore, the genotype AATT exhibitedthe highest frequency of distribution in both obese and Normal groups $(44.9 \%, 40 \%)$ respectively (Table 5). Genotype frequencies of normal and obese groups were shown in Table 5. The obese cases displayed frequencies of $44.9 \%(n=22), 14.3 \%(n=7), 6.1 \%(n=3) 2 \%(n=1)$, $28.6 \%(n=14)$, and $4.1 \%(n=2)$ for the following haplotypes AATT, AGTT, GGTT, AATC, AGTC, GGTC respectively. It was also noticed that the genotypes AACC, AGCC and GGCC were undetectable in obese cases only. Whereas the non-obese cases had 40\% $(n=24), 10 \%(n=6), 3.3 \%(n=2), 5 \%(n=3), 23.3 \%(n=14)$, $3.3 \%(n=2), 3.3 \%(n=2), 6.7 \%(n=4)$ and $5 \%(n=3)$. Moreover, the allele frequencies of obese group were found to be $67.3 \%(\mathrm{~N}=66), 1.02 \%(\mathrm{~N}=1), 15.3 \%(\mathrm{~N}=15)$ and $16.3 \%(\mathrm{~N}=16)$ for the following alleles AT, AC, GT and GC respectively. Where, in case of normal subjects, there were $59.2 \%(\mathrm{~N}=71), 9.2 \%(\mathrm{~N}=11), 10 \%(\mathrm{~N}=12)$ and $21.7 \%$ $(\mathrm{N}=26)$.

The distributions of genotypemet the Hardy-Weinberg expectations in both groups (normal and obese cases) (Goodness of fit X2 $=3.86, \mathrm{df}=1, \mathrm{P}=0.005$ ) (Goodness of fit $\mathrm{X} 2=7.09$, $\mathrm{df}=1, \mathrm{P}=0.01$ ) respectively.

Haplotype analysis betweenexon 6 A/ G (rs1137101) and exon 9 T/C (rs1805134) was carried out. All the possible haplotypes (AT, AC, GT and GC) were demonstrated with frequencies of $\mathrm{A}-\mathrm{A}=62.84 \%, \mathrm{AC}=5.5 \%, \mathrm{GT}=12.39 \%$ and $\mathrm{GC}=19.27 \%$ (Table 6). Ourresults shown that the haplotype A-T exon 6, exon 9 was the most common $(62.84 \%)$ whereas the frequency of other haplotypes, G-T and G-C was $12.39 \%$ and $19.27 \%$, respectively. The frequency of the rare haplotype A-C was 5.5\%. Haplotype analysis exhibiteda highly significant association with obesity $(\mathrm{P}=0.00001)$ as shown in Table 6.

\section{Allele and genotype frequencies of LEPR Lys109Arg (rs1137100), GIn223Arg (rs1137101), Ser343Ser (rs1805134) variants in 88 subjects:-}

The association between the presence of Lys109Arg (rs1137100), Gln223Arg(rs1137101), Ser343Ser (rs1805134)polymorphisms and incidence of obesity was shown in Table 7. This combination was analyzed in term of BMI classification groups (normal and obese). We defined twenty-seven genotypes but in this study only eighteen genotypes were recognized (AAAATT, AGAATT, GGAATT, AAAATC, AGAATC, AAAACC, AAAGTT, AGAGTT, AAAGTC, AGAGTC, AAAGCC, AGAGCC, AAGGTT, AGGGTT, AAGGTC, AGGGTC, AAGGCC and AGGGCC).Nosignificant association was found between all genotypes and BMI classes $(\mathrm{P}=0.196)$ as shown in Table 7.The analysis of genotypefrequencies revealed that the genotype AAAATT was the highest frequency distribution in obese and normal cases (42.2\% and 32.6\% respectively).The rare genotypes GGAATT, AGAATC, AGGGTT were only detected in obese cases, while they were undetectable in normal subjects. However, the genotypes AAAACC, AAAGCC, AGAGCC were found in normalcases only (Table 7, Figure 1).No significant difference in variation among genotypes $(\mathrm{P}=0.196)$ between obese and non-obese groups was found as shown in Table 7.

Haplotype analysis among exon 4 A/G Lys109Arg (rs1137100), exon 6 A/ G (rs1137101) and exon 9 T/C (rs1805134) was carried out. Eight possible haplotypes (AAT, AAC, AGT, AGC, GAT, GAC, GGT and GGC) were validated with frequencies of $\mathrm{A}-\mathrm{A}-\mathrm{T}=60.2 \%, \mathrm{~A}-\mathrm{A}-\mathrm{C}=4.5 \%, \mathrm{~A}-\mathrm{G}-\mathrm{T}=9.1 \%, \mathrm{~A}-\mathrm{G}-\mathrm{C}=15.3 \%, \mathrm{G}-\mathrm{A}-\mathrm{T}=3.4 \%$, G-A$\mathrm{C}=0.6 \%$, G-G-T=2.3\% and G-G-C=2.37\% (Table 7, Figure 2).Our obtained results revealed that the haplotype AA-Texon 4, exon 6, exon9 was the most common (60.2\%). whereas the frequency of other haplotypes, A-G-T and AG-C was $9.1 \%$ and $15.3 \%$, respectively. The frequency of the rare haplotype G-A-C was $0.6 \%$ as shown in Table 7 .

Haplotype analysis exhibited a highly significant association with obesity $(\mathrm{P}=0.0000)$. Additionally, figure 2 summarized the presence of significant haplotype frequencies in both obese and normal groups. It was obvious that there was a preference for the haplotype AAT at both groups obese and normal. Also, the absence of haplotype GAC in normal cases was documented, while a remarkable increasing in haplotype frequency of haplotypes AAC, GGC in obese subjects ( 7 fold) compared to those in normal cases was observed. Our results indicated that Lys109Arg (rs1137100), Gln223Arg(rs1137101), Ser343Ser (rs1805134) variants were highly polymorphic in the Saudi population. 


\section{Discussion:-}

Leptin (anti-obese hormone) belongs to class -1 helical cytokine. Inmammals, it secretes only by the adipose tissue and its action occurs mainly to regulate the amount of body fat deposits in relation to the available energy (Wang et al. 2004).Leptin receptor (OB-R) is a class -1 cytokine receptor family. It constitutes of long extracellular domain (816 amino acids) implicated in cell-cell interaction, intracellular domain (varied from 34 to 303 amino acids) possessing conserved motifs that have a crucial role in the intracellular signal transduction. The variation between OBR isoforms arises from alternative RNA splicing at the most C-terminal coding exon leading to the formation of different intracellular domain with different structure and length (Chen et al. 1996; Lee et al. 1996). Many polymorphisms in leptin receptor gene (LEPR) have been identified. However, its involvement as a haplotype block on obesity incidence is still controversial.

The current study was carried out to better understand the pathogenesis of obesity.Three mutations Lys109Arg, Gln223Arg, Ser343Ser in the extracellular domainof leptin receptor were used to put in evidence their possible association with morbid obesity in Saudi population in Jeddah.Our results demonstrated that of the three SNPs investigated a highly significant association in terms of linkage disequilibrium (LD) between exon 4 A/ G (rs1137100) and exon $6 \mathrm{~A} / \mathrm{G}$ (rs1137101) polymorphisms was observed ( $\mathrm{P}=0.017)$. Moreover, only allele AT (79\%) and genotype AATT for the combination of Lys109Arg, Ser343Ser SNPs werefound to be in associationwith morbid obesity. Whereas the forbidden AACC, AGCC genotypes were onlydetectablein normal cases. It was obvious that a highly significant association was observed when Lys109Arg and Ser343Ser polymorphisms were combined. This means thatthe combination of both SNPs exerted a synergic effect on incidence of obesity. Whereas the combination of Gln223Arg and Ser343Ser SNPs hadan antagonistic influence.Interestingly, the genotypes AACC, AGCC and GGCC of Gln223Arg and Ser343Ser SNPs was found only in normal cases. From all these results, we can conclude that the homozygote recessive genotype CC of Ser343Ser polymorphism showed a significant relationship with incidence of obesity when it was found in combination with Lys109Arg SNP. Previous studies illustrated that the association between Ser343Ser and obesity are controversial among different ethical populations. Our results were in agreement with the finding of(Mammes et al. 2001). Similarly, our finding was in accordance with that obtained by (Okada et al. 2010)who found that rs1805134 CC showed a significant association with low level of triglyceride. Ser343SerSNP is a synonymous amino acid variation found in the extracellular portion of leptin receptor. Many mutations defined in this domain which don't abolish completely its function are widely distributed(Takahashi-Yasuno et al. 2004).Similarly, several preceding studies monitored that the Q223R mutation has been associated with obesity,althoughothers illustrated no obvious association (van Rossum et al. 2003; Yiannakouris et al. 2001; Wauters et al. 2001; Heo et al. 2002).Additionally, the protective effect exerts by two polymorphisms (rs1137100 and rs1137101) to hypertension in men was documented, this protection was increased significantly in case of carriers with homozygotes arginine substitutions(Rosmond et al. 2000).

In addition, the association between Lys109Arg (rs1137100), Gln223Arg(rs1137101), Ser343Ser (rs1805134) polymorphisms and incidence of obesity was also analyzed in relation to BMI classification groups (normal and obese). No significant difference in variation among genotypes $(\mathrm{P}=0.196)$ between obese and non-obesesubjects was observed. It is apparent that only genotypes comprising recessive alleles (CC for Ser343Ser SNP) were found in normal cases and lacked in obese cases. There was a preference for TT/TC genotypes in obese cases whereas the CC genotypes were common in control subjects. A slight effect was exerted by others polymeric sites, Lys109Arg, Gln223Arg. It is obvious that the polymorphism Ser343Ser was the major player affecting significantly on obesity incidence. Our finding was agreed with that observed by (Rojano-Rodriguez et al. 2016). It seems that the other polymorphic sites Lys109Arg and Gln223Arg abolished the effect of each other on incidence of obesity.

As regardsthe haplotype analysis, a slightly significant association between haplotypes was observed when the three SNPs exon 4 A/G Lys109Arg (rs1137100), exon 6 A/ G (rs1137101) and exon 9 T/C (rs1805134)were combinedin obese patients and controls. Haplotypes AAC and GGC were highly distinct in normal subjects. However, when small combinations (Lys109Arg, Gln223Arg), (Lys109Arg, Ser343Ser) and (Gln223Arg, Ser343Ser) were investigated, a strong association was noticed $(\mathrm{P}=0.048, \mathrm{P}=0.028$ and $\mathrm{P}=0.00001$ respectively). From the obtained results, we summarized that of the three SNPs evaluated, only genotype TT/TC and allele T for Ser343Ser polymorphism was found in association with morbid obesity. This results were in discordance with that obtained by (Rojano-Rodriguez et al. 2016).

The interrogation about the possible effect of Ser343Ser polymorphism on morbid obesity is still unknown. This polymeric site was located in the extracellular domain of leptin receptor near the first cytokine motif (GXWSXWS). 
It is also found in the Ig like domain which has animportant role in the cell-cell interaction. Amino acid substitution in the extracellular domain exerts no impact on the binding affinity of the receptor but it strongly has an effect on cell surface expression (Chua et al. 1996). But, this silent mutation was not modifying the amino acid structure of leptin receptor. This effect seems arising from the tendency to use codon for most genes. There is a group of genes for which the codon choice is significantly biased. The major codons are found mainly with a relatively abundance of tRNA-gene for their corresponding amino acid. The availability of tRNA-gene affects strongly on the level of highly expressed proteins. Therefore, the genetic code is not a solid code(Andersson and Kurland 1990). Every organism has a specific preference toward one of the abundant codons coding the same amino acid. This preference reveals the structure of their individual genomic tRNA pool. It appears that ideal codons help to get faster rates of translation and great accuracy (Kotlar and Lavner 2006).

In conclusion, an association between Lys109Arg, and Ser343Ser polymorphisms was observed. There was a preference for genotypes TT/TC and allele T of Ser343Ser SNP in obese subjects. The effect of polymeric sites Lys109Arg, Gln223Arg on incidence of obesity was abolished when the three SNPs was combined. The only main player was Ser343Ser polymorphism. The influence of polymorphic site ser343ser on incidence of obesity may varies among populations due to distinct differences in their allele distributions.Finally, we recommend conducting additional study, including estimation of codon/tRNAinteraction, to explain the relationship between leptin receptor expression and susceptibility to morbid obesity. It was noted that, even with a limited sample size, the association of genetic variations in the LEPR gene exon $9 \mathrm{~T} / \mathrm{C}$ could play an important role in susceptibility for obesity.

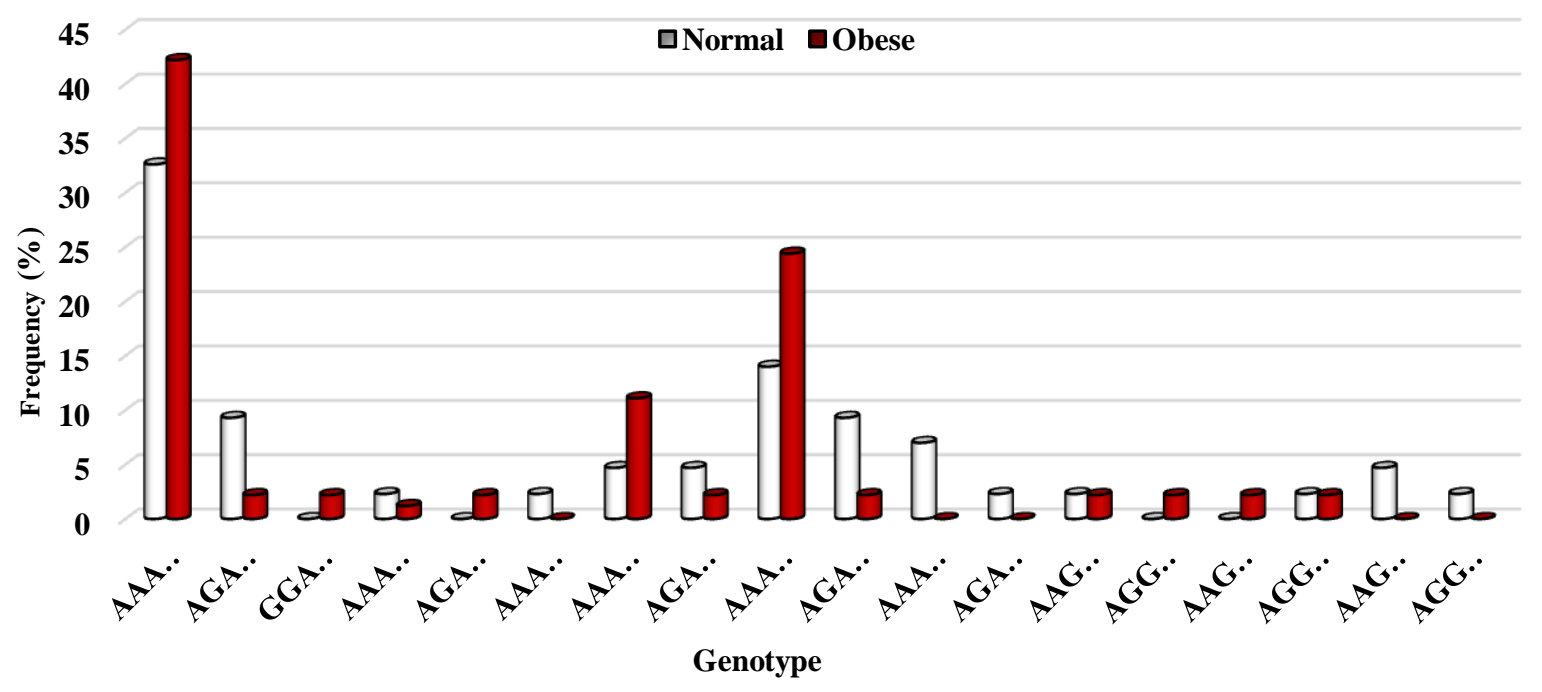

Figure 1:- Genotype frequencies in both groups (obese and normal) for LYS109ARG, GLN223ARG and SER343SER in 88 subjects. 


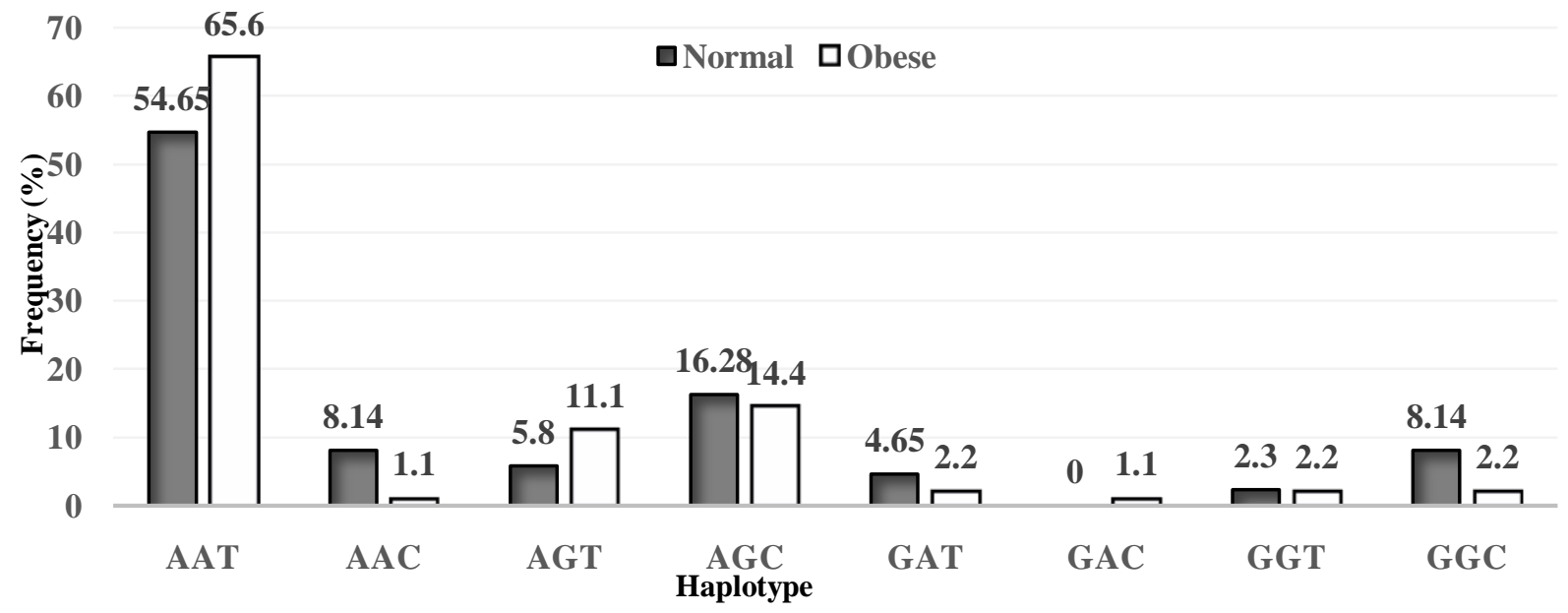

Figure2:- Inferred haplotype frequencies of normal and obese groups for LYS109ARG, GLN223ARG and SER343SER in 88 subjects.

Table 1:- Frequencies of genotype and allele for the combination of both polymorphisms (LYS109ARG and GLN223ARG) in 100subjects according to BMI Classification (Normal and Obese)

\begin{tabular}{|c|c|c|c|c|c|c|c|}
\hline \multirow{2}{*}{ Genotype } & \multicolumn{2}{|c|}{ BMI class } & \multirow[t]{2}{*}{ Total } & \multirow{2}{*}{$\mathrm{X}^{2} / \mathrm{P}$} & \multirow{2}{*}{ Allele } & \multirow{2}{*}{$\begin{array}{l}\mathrm{N} \\
\text { Normal }\end{array}$} & \multirow{2}{*}{$\begin{array}{l}\mathrm{N} \\
\text { Obese }\end{array}$} \\
\hline & Normal & Obese & & & & & \\
\hline AAAA & $\begin{array}{l}18 \\
35.3 \%\end{array}$ & $\begin{array}{l}22 \\
44.9 \%\end{array}$ & $\begin{array}{l}40 \\
40.0 \%\end{array}$ & \multirow[t]{7}{*}{$\begin{array}{l}6.125 / \\
0.38\end{array}$} & AA & \multirow{3}{*}{$\begin{array}{l}64 \\
62.7 \% \\
7 \\
6.9 \%\end{array}$} & \multirow{3}{*}{$\begin{array}{l}67 \\
68.37 \% \\
23 \\
23.47 \%\end{array}$} \\
\hline AGAA & $\begin{array}{l}7 \\
13.7 \%\end{array}$ & $\begin{array}{l}2 \\
4.1 \%\end{array}$ & $\begin{array}{l}9 \\
9.0 \%\end{array}$ & & \multirow[t]{2}{*}{ AG } & & \\
\hline AAAG & $\begin{array}{l}12 \\
23.5 \%\end{array}$ & $\begin{array}{l}17 \\
34.7 \%\end{array}$ & $\begin{array}{l}29 \\
29.0 \%\end{array}$ & & & & \\
\hline AGAG & $\begin{array}{l}9 \\
17.6 \%\end{array}$ & $\begin{array}{l}4 \\
8.2 \%\end{array}$ & $\begin{array}{l}13 \\
13.0 \%\end{array}$ & & GA & $\begin{array}{l}20 \\
19.6 \%\end{array}$ & $\begin{array}{l}2 \\
2.04 \%\end{array}$ \\
\hline AAGG & $\begin{array}{l}3 \\
5.9 \%\end{array}$ & $\begin{array}{l}2 \\
4.1 \%\end{array}$ & $\begin{array}{l}5 \\
5.0 \%\end{array}$ & & \multirow[t]{2}{*}{ GG } & \multirow{3}{*}{$\begin{array}{l}11 \\
10.9 \%\end{array}$} & \multirow{3}{*}{$\begin{array}{l}6 \\
6.12 \% \\
98\end{array}$} \\
\hline AGGG & $\begin{array}{l}2 \\
3.9 \%\end{array}$ & $\begin{array}{l}2 \\
4.1 \%\end{array}$ & $\begin{array}{l}4 \\
4.0 \%\end{array}$ & & & & \\
\hline Total & 51 & 49 & 100 & & Total & & \\
\hline
\end{tabular}

Table 2:- Linkage disequilibrium (LD) and inferred haplotype frequencies for LYS109ARG Exon 4 (A/G) (rs1137100) and GLN223ARG Exon 6 A/G (rs1137101) in 100 subjects.

\begin{tabular}{|l|l|l|l|l|l|l|}
\hline SNP1 & SNP2 & $\mathbf{D}^{\prime}$ & $\mathbf{R}^{2}$ & $\mathbf{X}^{2}$ & Haplotype & Frequency \\
& & & & & Haplotype & (\%) \\
\hline Exon 4 & Exon 6 & -1 & 0.0391 & 3.91 & A - A & 65.5 \\
(A/G) (rs1137100) & A/G (rs1137101) & & & & A - G & 21.5 \\
& & & & & G - A & 4.5 \\
& & & & & G - G & 8.5 \\
& & & & Total & 100 \\
\hline
\end{tabular}

$\mathrm{D}^{\prime}=$ the deviation of the observed frequency of a haplotype from the expected.

$\mathrm{X}^{2}=3.91$ indicated that there was significantly higher frequency of the allele haplotype in the subject $(\mathrm{P}=$ $0.048)$. 
Table 3:- Frequencies of genotype and allele for the combination of both polymorphisms (LYS109ARG and SER343SER) in 95subjects according to BMI Classification (Normal and Obese)

\begin{tabular}{|c|c|c|c|c|c|c|c|}
\hline \multirow[t]{2}{*}{ Genotype } & \multicolumn{2}{|c|}{ BMI Class } & \multirow[t]{2}{*}{ Total } & \multirow[t]{2}{*}{$\mathrm{X}^{2} / \mathrm{P}$} & \multirow[t]{2}{*}{ Alleles } & \multirow{2}{*}{$\begin{array}{l}\mathrm{N} \\
\text { Normal }\end{array}$} & \multirow{2}{*}{$\begin{array}{l}\mathrm{N} \\
\text { Obese }\end{array}$} \\
\hline & Normal & Obese & & & & & \\
\hline AATT & $\begin{array}{l}17 \\
37.8 \% \\
\end{array}$ & $\begin{array}{l}29 \\
58.0 \% \\
\end{array}$ & $\begin{array}{l}46 \\
48.4 \% \\
\end{array}$ & \multirow[t]{7}{*}{$\begin{array}{l}13.89 / \\
0.017\end{array}$} & \multirow[t]{2}{*}{ AT } & \multirow{3}{*}{$\begin{array}{l}54 \\
60 \% \\
21 \\
23.3 \%\end{array}$} & $\begin{array}{l}79 \\
79 \%\end{array}$ \\
\hline AGTT & $\begin{array}{l}8 \\
17.8 \% \\
\end{array}$ & $\begin{array}{l}5 \\
10.0 \% \\
\end{array}$ & $\begin{array}{l}13 \\
13.7 \% \\
\end{array}$ & & & & \multirow{2}{*}{$\begin{array}{l}13 \\
13 \%\end{array}$} \\
\hline AATC & $\begin{array}{l}7 \\
15.6 \% \\
\end{array}$ & $\begin{array}{l}13 \\
26.0 \% \\
\end{array}$ & $\begin{array}{l}20 \\
21.1 \% \\
\end{array}$ & & $\mathrm{AC}$ & & \\
\hline AGTC & $\begin{array}{l}5 \\
11.1 \%\end{array}$ & $\begin{array}{l}3 \\
6.0 \%\end{array}$ & $\begin{array}{l}8 \\
8.4 \%\end{array}$ & & GT & \multirow{4}{*}{$\begin{array}{l}8 \\
8.9 \% \\
7 \\
7.8 \%\end{array}$} & \multirow{4}{*}{$\begin{array}{l}5 \\
5 \% \\
3 \\
3 \% \\
100\end{array}$} \\
\hline AACC & $\begin{array}{l}6 \\
13.3 \%\end{array}$ & 0 & $\begin{array}{l}6 \\
6.3 \%\end{array}$ & & \multirow{3}{*}{$\begin{array}{l}\text { GC } \\
\text { Total }\end{array}$} & & \\
\hline AGCC & $\begin{array}{l}2 \\
4.4 \% \\
\end{array}$ & 0 & $\begin{array}{l}2 \\
2.1 \% \\
\end{array}$ & & & & \\
\hline Total & 45 & 50 & 95 & & & & \\
\hline
\end{tabular}

Table 4:- Linkage disequilibrium (LD) and inferred haplotype frequencies for LYS109ARG Exon 4 (A/G) (rs1137100) andser343ser Exon 9 (T/C) (rs1805134) in 95 subjects.

\begin{tabular}{|c|c|c|c|c|c|c|}
\hline \multirow[t]{2}{*}{ SNP1 } & \multirow[t]{2}{*}{ SNP2 } & \multirow[t]{2}{*}{$\mathbf{D}^{\prime}$} & \multirow[t]{2}{*}{$\mathbf{R}^{2}$} & \multirow[t]{2}{*}{$\mathbf{X}^{2}$} & Haplotype & \multirow{2}{*}{$\begin{array}{l}\text { Frequency } \\
(\%)\end{array}$} \\
\hline & & & & & Haplotype & \\
\hline $\begin{array}{l}\text { Exon } 4 \\
(\mathrm{~A} / \mathrm{G})(\mathrm{rs} 1137100)\end{array}$ & $\begin{array}{l}\text { Exon } 9 \\
\mathrm{~T} / \mathrm{C}(\mathrm{rs} 1805134)\end{array}$ & -1 & 0.0028 & 4.8 & $\begin{array}{l}A-T \\
A-C \\
G-T \\
G-C \\
\text { Total }\end{array}$ & $\begin{array}{l}70 \\
17.9 \\
6.8 \\
0.5 \\
100 \\
\end{array}$ \\
\hline
\end{tabular}

$\mathrm{D}^{\prime}=$ the deviation of the observed frequency of a haplotype from the expected.

$\mathrm{X}^{2}=4.8$ indicated that there was significantly higher frequency of the allele haplotype in the subject $(\mathrm{P}=0.028)$.

Table 5:- Frequencies of genotype and allele for the combination of both polymorphisms (GLN223ARG and SER343SER) in 109subjects according to BMI Classification (Normal and Obese).

\begin{tabular}{|c|c|c|c|c|c|c|c|}
\hline \multirow[t]{2}{*}{ Genotype } & \multicolumn{2}{|c|}{ BMI class } & \multirow[t]{2}{*}{ Total } & \multirow[t]{2}{*}{$\mathrm{X}^{2} / \mathrm{P}$} & \multirow[t]{2}{*}{ Allele } & \multirow{2}{*}{$\begin{array}{l}\mathrm{N} \\
\text { Normal }\end{array}$} & \multirow{2}{*}{$\begin{array}{l}\mathrm{N} \\
\text { Obese }\end{array}$} \\
\hline & Normal & Obese & & & & & \\
\hline AATT & $\begin{array}{l}24 \\
40.0 \%\end{array}$ & $\begin{array}{l}22 \\
44.9 \% \\
\end{array}$ & $\begin{array}{l}46 \\
42.2 \%\end{array}$ & \multirow[t]{10}{*}{$9.349 / 0.195$} & \multirow{3}{*}{$\begin{array}{l}\text { AT } \\
\text { AC }\end{array}$} & \multirow{10}{*}{$\begin{array}{l}71 \\
59.2 \% \\
11 \\
9.2 \%\end{array}$} & \multirow{10}{*}{$\begin{array}{l}66 \\
67.3 \% \\
1 \\
1.02 \%\end{array}$} \\
\hline AGTT & $\begin{array}{l}6 \\
10.0 \% \\
\end{array}$ & $\begin{array}{l}7 \\
14.3 \%\end{array}$ & $\begin{array}{l}13 \\
11.9 \%\end{array}$ & & & & \\
\hline GGTT & $\begin{array}{l}2 \\
3.3 \% \\
\end{array}$ & $\begin{array}{l}3 \\
6.1 \%\end{array}$ & $\begin{array}{l}5 \\
4.6 \%\end{array}$ & & & & \\
\hline AATC & $\begin{array}{l}3 \\
5.0 \%\end{array}$ & $\begin{array}{l}1 \\
2.0 \%\end{array}$ & $\begin{array}{l}4 \\
3.7 \%\end{array}$ & & \multirow{7}{*}{$\begin{array}{l}\text { GT } \\
\text { GC } \\
\text { Total }\end{array}$} & & \\
\hline AGTC & $\begin{array}{l}14 \\
23.3 \%\end{array}$ & $\begin{array}{l}14 \\
28.6 \%\end{array}$ & $\begin{array}{l}28 \\
25.7 \%\end{array}$ & & & & \\
\hline GGTC & $\begin{array}{l}2 \\
3.3 \% \\
\end{array}$ & $\begin{array}{l}2 \\
4.1 \% \\
\end{array}$ & $\begin{array}{l}4 \\
3.7 \% \\
\end{array}$ & & & & \\
\hline AACC & $\begin{array}{l}2 \\
3.3 \% \\
\end{array}$ & 0 & $\begin{array}{l}2 \\
1.8 \%\end{array}$ & & & & \\
\hline AGCC & $\begin{array}{l}4 \\
6.7 \%\end{array}$ & 0 & $\begin{array}{l}4 \\
3.7 \%\end{array}$ & & & & \\
\hline GGCC & $\begin{array}{l}3 \\
5.0 \% \\
\end{array}$ & 0 & $\begin{array}{l}3 \\
2.8 \% \\
\end{array}$ & & & & \\
\hline Total & 60 & 49 & 109 & & & & \\
\hline
\end{tabular}


Table 6:- Linkage disequilibrium (LD) and inferred haplotype frequencies for GLN223ARG Exon 6 A/G (rs1137101) and SER343SER Exon 9 (T/C) (rs1805134) in 109 subjects.

\begin{tabular}{|c|c|c|c|c|c|c|}
\hline \multirow[t]{2}{*}{ SNP1 } & \multirow[t]{2}{*}{ SNP2 } & \multirow[t]{2}{*}{$\mathbf{D}^{\prime}$} & \multirow[t]{2}{*}{$\mathbf{R}^{2}$} & \multirow[t]{2}{*}{$\mathbf{X}^{2}$} & Haplotype & \multirow[t]{2}{*}{ Frequency (\%) } \\
\hline & & & & & Haplotype & \\
\hline $\begin{array}{l}\text { Exon } 6 \\
(\mathrm{~A} / \mathrm{G})(\mathrm{rs} 1137101)\end{array}$ & $\begin{array}{l}\text { Exon } 9 \\
\text { T/C (rs1805134) }\end{array}$ & 0.622 & 0.2753 & 30.01 & $\begin{array}{l}A-T \\
A-C \\
G-T \\
G-C \\
\text { Total }\end{array}$ & $\begin{array}{l}62.84 \% \\
5.5 \% \\
12.39 \% \\
19.27 \% \\
100\end{array}$ \\
\hline
\end{tabular}

$\mathrm{D}^{\prime}=$ the deviation of the observed frequency of a haplotype from the expected.

$\mathrm{X}^{2}=30.01$ indicated that there was significantly higher frequency of the allele haplotype in the subject $(\mathrm{P}=$ 0.00001).

Table 7:- Frequencies of genotype and allele for the combination of three polymorphisms (LYS109ARG, GLN223ARG and Ser343Ser) according to BMI classification in 88 subject.

\begin{tabular}{|c|c|c|c|c|c|c|c|c|}
\hline \multirow[t]{2}{*}{ Genotype } & \multicolumn{2}{|c|}{ BMI Class } & \multirow{2}{*}{$\begin{array}{l}\mathbf{N} \\
(n=88)\end{array}$} & \multirow[t]{2}{*}{$\mathrm{X}^{2} / \mathrm{P}$} & \multirow[t]{2}{*}{ Haplotype } & \multirow{2}{*}{$\begin{array}{l}\mathrm{N} \\
\text { Normal }\end{array}$} & \multirow{2}{*}{$\begin{array}{l}\mathrm{N} \\
\text { Obese }\end{array}$} & \multirow{2}{*}{$\begin{array}{l}\mathrm{N} \\
\text { Total }\end{array}$} \\
\hline & $\begin{array}{l}\text { Normal } \\
(n=43)\end{array}$ & $\begin{array}{l}\text { Obese } \\
(n=45)\end{array}$ & & & & & & \\
\hline AAAATT & $\begin{array}{l}14 \\
32.6 \%\end{array}$ & $\begin{array}{l}19 \\
42.2 \%\end{array}$ & $\begin{array}{l}33 \\
37.5 \%\end{array}$ & \multirow[t]{19}{*}{$\begin{array}{l}19.412 / \\
0.196\end{array}$} & \multirow{19}{*}{$\begin{array}{l}\text { AAT } \\
\text { AAC } \\
\text { AGT } \\
\text { AGC } \\
\text { GAT } \\
\text { GAC } \\
\text { GGT } \\
\text { GGC } \\
\text { Total }\end{array}$} & \multirow{4}{*}{$\begin{array}{l}47 \\
54.65 \% \\
7 \\
8.14 \%\end{array}$} & \multirow[t]{2}{*}{$\begin{array}{l}59 \\
65.6 \%\end{array}$} & \multirow[t]{2}{*}{$\begin{array}{l}106 \\
60.2 \%\end{array}$} \\
\hline AGAATT & $\begin{array}{l}4 \\
9.3 \%\end{array}$ & $\begin{array}{l}1 \\
2.2 \%\end{array}$ & $\begin{array}{l}5 \\
5.7 \%\end{array}$ & & & & & \\
\hline GGAATT & 0 & $\begin{array}{l}1 \\
2.2 \%\end{array}$ & $\begin{array}{l}1 \\
1.1 \%\end{array}$ & & & & $\begin{array}{l}1 \\
1.1 \%\end{array}$ & $\begin{array}{l}8 \\
4.5 \%\end{array}$ \\
\hline AAAATC & $\begin{array}{l}1 \\
2.3 \%\end{array}$ & $1.2 \%$ & $\begin{array}{l}2 \\
2.3 \%\end{array}$ & & & & & \\
\hline AGAATC & 0 & $\begin{array}{l}1 \\
2.2 \%\end{array}$ & $1.1 \%$ & & & $\begin{array}{ll}5 & \\
& 5.8 \%\end{array}$ & $\begin{array}{l}10 \\
11.1 \%\end{array}$ & $\begin{array}{l}16 \\
9.1 \%\end{array}$ \\
\hline AAAACC & $\begin{array}{l}1 \\
2.3 \%\end{array}$ & 0 & $\begin{array}{l}1 \\
1.1 \%\end{array}$ & & & & & \\
\hline AAAGTT & $\begin{array}{l}2 \\
4.7 \% \\
\end{array}$ & $\begin{array}{l}5 \\
11.1 \%\end{array}$ & $\begin{array}{l}7 \\
8.0 \%\end{array}$ & & & $\begin{array}{l}14 \\
16.28 \%\end{array}$ & $\begin{array}{l}13 \\
14.4 \%\end{array}$ & $\begin{array}{l}26 \\
15.3 \%\end{array}$ \\
\hline AGAGTT & $\begin{array}{l}2 \\
4.7 \%\end{array}$ & $\begin{array}{l}1 \\
2.2 \%\end{array}$ & $\begin{array}{l}3 \\
3.4 \%\end{array}$ & & & & & \\
\hline AAAGTC & $\begin{array}{l}6 \\
14.0 \% \\
\end{array}$ & $\begin{array}{l}11 \\
24.4 \%\end{array}$ & $\begin{array}{l}17 \\
19.3 \%\end{array}$ & & & $\begin{array}{l}4 \\
4.65 \%\end{array}$ & $\begin{array}{l}2 \\
2.2 \%\end{array}$ & $\begin{array}{l}6 \\
3.4 \%\end{array}$ \\
\hline AGAGTC & $\begin{array}{l}4 \\
9.3 \%\end{array}$ & $\begin{array}{l}1 \\
2.2 \%\end{array}$ & $\begin{array}{l}5 \\
5.7 \%\end{array}$ & & & & & \\
\hline AAAGCC & $\begin{array}{l}3 \\
7.0 \% \\
\end{array}$ & 0 & $\begin{array}{l}3 \\
3.4 \%\end{array}$ & & & $\begin{array}{l}0 \\
0.0 \%\end{array}$ & $\begin{array}{l}1 \\
1.1 \%\end{array}$ & $\begin{array}{l}1 \\
0.6 \%\end{array}$ \\
\hline AGAGCC & $\begin{array}{l}1 \\
2.3 \%\end{array}$ & 0 & $\begin{array}{l}1 \\
1.1 \%\end{array}$ & & & & & \\
\hline AAGGTT & $\begin{array}{l}2.5 \% \\
1 \\
2.3 \% \\
\end{array}$ & $\begin{array}{l}1 \\
2.2 \% \\
\end{array}$ & $\begin{array}{l}2 \\
2.3 \% \\
\end{array}$ & & & $\begin{array}{l}2 \\
2.3 \%\end{array}$ & $\begin{array}{l}2 \\
2.2 \%\end{array}$ & $\begin{array}{l}4 \\
2.3 \%\end{array}$ \\
\hline AGGGTT & 0 & $\begin{array}{l}1 \\
2.2 \%\end{array}$ & $\begin{array}{l}1 \\
1.1 \%\end{array}$ & & & & & \\
\hline AAGGTC & 0 & $\begin{array}{l}1 \\
2.2 \%\end{array}$ & $\begin{array}{l}1 \\
1.1 \%\end{array}$ & & & $8.14 \%$ & $2.2 \%$ & $5.11 \%$ \\
\hline AGGGTC & $\begin{array}{l}1 \\
2.3 \%\end{array}$ & $\begin{array}{l}1 \\
2.2 \%\end{array}$ & $\begin{array}{l}2 \\
2.3 \%\end{array}$ & & & 86 & 90 & 176 \\
\hline AAGGCC & $\begin{array}{l}2 \\
4.7 \%\end{array}$ & 0 & $\begin{array}{l}2 \\
2.3 \%\end{array}$ & & & & & \\
\hline AGGGCC & $\begin{array}{l}1 \\
2.3 \%\end{array}$ & 0 & $\begin{array}{l}1 \\
1.1 \%\end{array}$ & & & & & \\
\hline Total & 43 & 45 & 88 & & & & & \\
\hline
\end{tabular}




\section{Reference:-}

1. Al-Nozha, M. M., Y. Y. Al-Mazrou, M. A. Al-Maatouq, M. R. Arafah, M. Z. Khalil, N. B. Khan, K. AlMarzouki, M. A. Abdullah, A. H. Al-Khadra, S. S. Al-Harthi, M. S. Al-Shahid, A. Al-Mobeireek, and M. S. Nouh. 2005. 'Obesity in Saudi Arabia', Saudi Med J, 26: 824-9.

2. Al-Sultan, A. I., and A. H. Al-Elq. 2006. 'Leptin levels in normal weight and obese saudi adults', J Family Community Med, 13: 97-102.

3. Andersson, S. G., and C. G. Kurland. 1990. 'Codon preferences in free-living microorganisms', Microbiol Rev, 54: 198-210.

4. Arslan, N., B. Erdur, and A. Aydin. 2010. 'Hormones and cytokines in childhood obesity', Indian Pediatr, 47: 829-39.

5. Bagchi, D., and Preuss, H. G. 2007. Obesity: epidemiology, pathophysiology, and prevention, Boca Raton: CRC Press. 1407-1433.

6. Bahathiq, A. O.S. 2010. Relationship of Leptin Hormones with Body Mass Index and Waist Circumference in Saudi Female Population of the Makkah Community, The Open Obesity Journal, 2: 95-100.

7. Bjorbaek, C., and B. B. Kahn. 2004. 'Leptin signaling in the central nervous system and the periphery', Recent Prog Horm Res, 59: 305-31.

8. Chen, H., O. Charlat, L. A. Tartaglia, E. A. Woolf, X. Weng, S. J. Ellis, N. D. Lakey, J. Culpepper, K. J. Moore, R. E. Breitbart, G. M. Duyk, R. I. Tepper, and J. P. Morgenstern. 1996. 'Evidence that the diabetes gene encodes the leptin receptor: identification of a mutation in the leptin receptor gene in db/db mice', Cell, 84: 491 5 .

9. Chua, S. C., Jr., D. W. White, X. S. Wu-Peng, S. M. Liu, N. Okada, E. E. Kershaw, W. K. Chung, L. PowerKehoe, M. Chua, L. A. Tartaglia, and R. L. Leibel. 1996. 'Phenotype of fatty due to Gln269Pro mutation in the leptin receptor (Lepr)', Diabetes, 45: 1141-3.

10. Chung, W. K., L. Power-Kehoe, M. Chua, and R. L. Leibel. 1996. 'Mapping of the OB receptor to $1 p$ in a region of nonconserved gene order from mouse and rat to human', Genome Res, 6: 431-8.

11. Clement, K., C. Vaisse, N. Lahlou, S. Cabrol, V. Pelloux, D. Cassuto, M. Gourmelen, C. Dina, J. Chambaz, J. M. Lacorte, A. Basdevant, P. Bougneres, Y. Lebouc, P. Froguel, and B. Guy-Grand. 1998. 'A mutation in the human leptin receptor gene causes obesity and pituitary dysfunction', Nature, 392: 398-401.

12. Fan, S. H., and Y. H. Say. 2014. 'Leptin and leptin receptor gene polymorphisms and their association with plasma leptin levels and obesity in a multi-ethnic Malaysian suburban population', J Physiol Anthropol, 33 : 15.

13. Fruhbeck, G. 2001. 'A heliocentric view of leptin', Proc Nutr Soc, 60: 301-18.

14. Gotoda, T., B. S. Manning, A. P. Goldstone, H. Imrie, A. L. Evans, A. D. Strosberg, P. M. Mckeigue, J. Scott, and T. J. Aitman. 1997. 'Leptin receptor gene variation and obesity: lack of association in a white British male population', Hum Mol Genet, 6: 869-76.

15. Guerola, S. J. V. 2008. Obesidad y alteraciones metabólicas: Factores genéticos yambientales en población mediterránea española, ,Ph.D. Thesis, Universitat de València.Departament de Medicina Preventiva, Salut Pública, Bromatologia, Toxicologia i Medicina Legal, Spain Valencia

16. Heo, M., R. L. Leibel, K. R. Fontaine, B. B. Boyer, W. K. Chung, M. Koulu, M. K. Karvonen, U. Pesonen, A. Rissanen, M. Laakso, M. I. Uusitupa, Y. Chagnon, C. Bouchard, P. A. Donohoue, T. L. Burns, A. R. Shuldiner, K. Silver, R. E. Andersen, O. Pedersen, S. Echwald, T. I. Sorensen, P. Behn, M. A. Permutt, K. B. Jacobs, R. C.

17. Elston, D. J. Hoffman, E. Gropp, and D. B. Allison. 2002. 'A meta-analytic investigation of linkage and association of common leptin receptor (LEPR) polymorphisms with body mass index and waist circumference', Int J Obes Relat Metab Disord, 26: 640-6.

18. Kotlar, D., and Y. Lavner. 2006. 'The action of selection on codon bias in the human genome is related to frequency, complexity, and chronology of amino acids', BMC Genomics, 7: 67.

19. Lee, G. H., R. Proenca, J. M. Montez, K. M. Carroll, J. G. Darvishzadeh, J. I. Lee, and J. M. Friedman. 1996. 'Abnormal splicing of the leptin receptor in diabetic mice', Nature, 379: 632-5.

20. Linjawi, S. A. M. And Al-Harbi Sh. M. A. 2014. Impact of Leptin Receptor Gene LYS109ARG Polymorphism on Obesity in Jeddah City. Life Science Journal. 11(7): 856-865.

21. Linjawi, S. A. And Al-Sayed, R. A. 2013. Impact of Leptin Receptor geneser343ser Polymorphism on Obesity injeddah City, Journal of American Science, 9(9) : 1-10.

22. Linjawi, S. A. And Hussain, N. A. 2012.Impact of Leptin Receptor Gene GLN223ARGPolymorphism on Obesity in Jeddah City, lifescience Journal, 9(4) : 818- 828.

23. Malnick, S. D., and H. Knobler. 2006. 'The medical complications of obesity', QJM, 99: 565-79. 
24. Mammes, O., R. Aubert, D. Betoulle, F. Pean, B. Herbeth, S. Visvikis, G. Siest, and F. Fumeron. 2001. 'LEPR gene polymorphisms: associations with overweight, fat mass and response to diet in women', Eur J Clin Invest, 31: 398-404.

25. Margetic, S., C. Gazzola, G. G. Pegg, and R. A. Hill. 2002. 'Leptin: a review of its peripheral actions and interactions', Int J Obes Relat Metab Disord, 26: 1407-33.

26. Marti, A., J. L. Santos, M. Gratacos, M. J. Moreno-Aliaga, A. Maiz, J. A. Martinez, and X. Estivill. 2009. 'Association between leptin receptor (LEPR) and brain-derived neurotrophic factor (BDNF) gene variants and obesity: a case-control study', Nutr Neurosci, 12: 183-8.

27. Okada, T., T. Ohzeki, Y. Nakagawa, S. Sugihara, and O. Arisaka. 2010. 'Impact of leptin and leptin-receptor gene polymorphisms on serum lipids in Japanese obese children', Acta Paediatr, 99.

28. Rojano-Rodriguez, Martin Edgardo, Jose Luis Beristain-Hernandez, Beatriz Zavaleta-Villa, Pablo Maravilla, Mirza Romero-Valdovinos, and Angelica Olivo-Diaz. 2016. 'Leptin receptor gene polymorphisms and morbid obesity in Mexican patients', Hereditas, 153: 1-5.

29. Rosmond, R., Y. C. Chagnon, G. Holm, M. Chagnon, L. Perusse, K. Lindell, B. Carlsson, C. Bouchard, and P. Bjorntorp. 2000. 'Hypertension in obesity and the leptin receptor gene locus', J Clin Endocrinol Metab, 85: 3126-31.

30. Takahashi-Yasuno, A., H. Masuzaki, T. Miyawaki, N. Matsuoka, Y. Ogawa, T. Hayashi, K. Hosoda, Y. Yoshimasa, G. Inoue, and K. Nakao. 2004. 'Association of Ob-R gene polymorphism and insulin resistance in Japanese men', Metabolism, 53: 650-4.

31. Turconi G, Cena H. 2007. Epidemiology of Obesity In: Obesity: epidemiology, pathophysiology, and prevention. Bagchi D, Preuss HG, Boca Raton FL, editor. CRC Press; pp. 3-19.

32. Van Rossum, C. T., B. Hoebee, M. A. Van Baak, M. Mars, W. H. Saris, and J. C. Seidell. 2003. 'Genetic variation in the leptin receptor gene, leptin, and weight gain in young Dutch adults', Obes Res, 11: 377-86.

33. Wang, Y., B. Jones Voy, S. Urs, S. Kim, M. Soltani-Bejnood, N. Quigley, Y. R. Heo, M. Standridge, B. Andersen, M. Dhar, R. Joshi, P. Wortman, J. W. Taylor, J. Chun, M. Leuze, K. Claycombe, A. M. Saxton, and N. Moustaid-Moussa. 2004. 'The human fatty acid synthase gene and de novo lipogenesis are coordinately regulated in human adipose tissue', J Nutr, 134: 1032-8.

34. Wauters, M., I. Mertens, T. Rankinen, M. Chagnon, C. Bouchard, and L. Van Gaal. 2001. 'Leptin receptor gene polymorphisms are associated with insulin in obese women with impaired glucose tolerance', J Clin Endocrinol Metab, 86: 3227-32.

35. World Health Organization .2011. Saudi Arabia_NCD _ profile, Saudi Arabia, World Health Organization.

36. Yiannakouris, N., M. Yannakoulia, L. Melistas, J. L. Chan, D. Klimis-Zacas, and C. S. Mantzoros. 2001. 'The Q223R polymorphism of the leptin receptor gene is significantly associated with obesity and predicts a small percentage of body weight and body composition variability', J Clin Endocrinol Metab, 86: 4434-9. 